\title{
"I Paid No Attention To It": An Oral History of Curricular Change in the 1930s
}

\author{
Patrice Milewski
}

Laurentian University

\section{ABSTRACT}

In 1937 the Ontario Department of Education introduced unprecedented changes to the curriculum and pedagogy of the elementary schools of the province through the publication and distribution of the document Programme of Studies for Grades 1 to VI of the Public and Separate Schools. By exploring the oral history of twenty-one teachers who taught in the elementary schools of Ontario during the 1930s, this article will explain how teachers understood and experienced the pedagogical and curricular changes introduced in 1937. Juxtaposing the oral history of teachers with the evidence of documentary sources will provide a means of creating a more nuanced account of the unprecedented reforms that were attempted in 1930s Ontario.

\section{RÉSUMÉ}

En 1937, avec la parution du Programme d'études pour les écoles publiques et séparées de l'Ontario, le Département de l'éducation apporta des changements sans précédent au programme

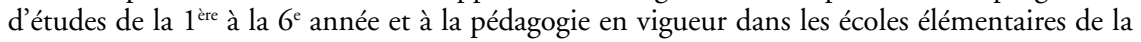
province. C'est à partir de témoignages recueillis auprès de 21 personnes ayant enseigné à ce niveau durant les années 1930 que nous analysons la réaction des enseignants face à ces changements introduits cette année-là. La comparaison de ces entretiens avec les sources documentaires permettra de nuancer davantage les résultats de ces réformes sans précédent entreprises en Ontario à cette époque.

\section{Introduction}

In 1937 the Ontario Department of Education introduced unprecedented changes to the curriculum and pedagogy of the elementary schools of the province through the publication and distribution of the document, Programme of Studies for Grades 1 to VI of the Public and Separate Schools. ${ }^{1}$ Historians have agreed that the changes heralded by this document were significant and have offered varying reasons for their assessment of the failure or success of these reforms. For example, W.G. Fleming argued that the new programme of studies foundered because the short period of teacher training after the war failed to induce teachers to "abandon the patterns by which 
they themselves had been taught." ${ }^{2}$ Robert Stamp, on the other hand, ascribed failure to political change by arguing that the election of the Conservatives in 1943 "marked the death-knell" of the curriculum introduced by the Liberals. ${ }^{3}$

The reforms in Ontario occurred between 1930 and 1945, a period, according to Robert Patterson, which bore the imprint of "progressive education." ${ }^{4}$ Amy von Heyking offers a nuanced understanding of educational reforms introduced in Alberta in 1935, by identifying three strands of that phenomenon. ${ }^{5}$ Her analysis links the educational changes in Alberta to the efforts of an emerging group of professional and progressive educationalists that viewed education as means of achieving social reform. Lemisko and Clausen's comparison of Ontario education reforms with those in Alberta during the same time concluded that success in both was hindered by inadequate training of pre-service and in-service teachers and a lack of resources to develop materials that would support the new approaches. ${ }^{6}$ This assessment concurs with those made by Patterson who suggested that the policy level commitment to implementing "progressive" education across Canada was only partial with the result that reforms were "never given a fair or extensive trial."

The education reforms of the 1930s took place against the backdrop of an historical crisis that remains a benchmark by which all subsequent crises are measured. Reynolds and Smaller identified some of the impacts that economic decline had on the Ontario school system. ${ }^{7}$ They found that during the 1930s the salaries of teachers in Ontario fell significantly, the percentage of men in teaching increased especially in rural areas, and the average age of teachers rose. ${ }^{8}$ The structural features they identified can also be viewed as impediments to education reform. Reynolds and Smaller noted that each village and rural school during the 1930s was administered by its own set of three local usually male trustees. ${ }^{9}$ The result was that entering the 1930 s there were 14,055 teachers in Ontario employed by 8,000 different employers which led to very uneven working/teaching conditions, quantity of resources, rates of pay, etc. ${ }^{10}$ The reforms were implemented by a predominantly female workforce supervised by an all male inspectorate. ${ }^{11}$ This reinforces a view of elementary schooling as a site where hierarchical and gendered relations of power/knowledge were enacted and that were, to a certain extent, reflected in the oral testimony of some of the women in this study.

This study utilizes the method of oral history to examine how the attempt to create curricular and pedagogical reform in the elementary schools of Ontario was received, understood and experienced by teachers. It draws on the oral testimony of seventeen women and four men who taught elementary school in various regions of the province during the 1930s. Examining this oral history will contribute to understanding the nature of teaching during the 1930s, particularly in village and rural communities, and a means of assessing the successes and failures of curricular and pedagogical reform in Ontario.

\section{Methodology}

This article is based on oral history interviews with 21 teachers (17 women and four men) who taught elementary school for significant periods of time in various regions 
of Ontario during the 1930s. The majority of the participants (14) taught in or near Toronto; however, of these 14, five actually began their careers acquiring experience in outlying areas before migrating to the metropolis. As a result, all but six of the teachers had experienced teaching in one-room rural schools in various regions of Ontario. The teachers were self-selecting in that they volunteered to participate in the study. Advertisements in retired teachers' association newsletters and word-ofmouth - the "snowballing" method — were the primary means of soliciting participants. The participants were aware that the interviewer was employed as a teacher during the time that the interviews were conducted. As a result, they were especially keen to share their recollections and "assist" a fellow teacher. ${ }^{12}$

As with all oral history work, and the fact that many of the teachers were aged and had been retired for quite some time, memory stood out as a central concern in this project. This concern is one that has been regularly addressed by oral historians. ${ }^{13}$ Luisa Passerini for example argues that "all autobiographical memory is true; it is up to the interpreter to discover in which sense, where, for what purpose." 14 Recognizing the propensity for subjects to engage in storytelling, Angela Davis recently pointed out that memory can be distorted by external constraints and that oral data needs to be compared with other accounts just as with all other sources. ${ }^{15}$

Ian Hacking's nominalist approach to examining the emergence of the sciences of memory in the late nineteenth century studies of multiple personality revealed - amongst other things - the socially constructed nature of the concept or idea of memory. ${ }^{16}$ These sciences of memory created new objects of knowledge and new kinds of facts overridden with political connotations. ${ }^{17}$ They emerged, wrote Hacking, "as surrogate sciences of the soul, empirical sciences, positive science that would provide new kinds of knowledge in terms of which to cure, help, and control the one aspect of human beings that had hitherto been outside science." 18 The relevance of Hacking's work for this study lies precisely in understanding how the memory about particular events such as the curriculum revisions that occurred in Ontario (and elsewhere) during the 1930s were formed and reformed through their politicization. ${ }^{19}$

As with the multi-year oral history project led by Rebecca Coulter and Helen Harper, respect for the interviewees, some of whom were 90 years of age, this project employed a very cautious approach. ${ }^{20}$ Hence, there was a reluctance to press forward with troubling questions or challenge points of view such as those which expressed bigotry or intolerance. There was also a tendency for teachers to present what Coulter and Harper identified as uncritical narratives that romanticized their relationship to teaching. ${ }^{21}$ On the other hand, teachers made statements that reflected an understanding of the deeper questions and difficulties besetting the method of oral history. Such was the case of Louise whose career in elementary education spanned 45 years and included becoming a principal in the 1950s. When asked about the role of the board of education in determining curriculum during the 1930s, she responded: "There are a lot of these things that we teachers don't really know very much about. It's only what we imagine... the impressions that are left with us and I maybe said things that hundreds of others wouldn't agree with." 22 


\section{Twenty-one Teachers}

The 17 women and four men who participated in this project do not represent the diversity of teaching experiences in Ontario during the 1930s. However, the proportion of women to men is close to being representative of the division of labour in the elementary public schools of Ontario that has been approximately 80 percent female since the early twentieth century. All of the teachers were white, middle class and Canadian born. The majority (18) identified themselves as having an Anglo-Saxon Protestant background. There were four exceptions: one woman had an eastern European background; another reported being French-Canadian; one woman was Anglo-Saxon Catholic; and one man identified himself as Jewish. Both the French Canadian woman and the Anglo Saxon Catholic woman taught in the public school system during the 1930s but moved to the Catholic separate school system much later in their careers.

Seven of the 18 women never married and of these seven, one left the teaching profession during the 1940s to take a position with the Department of Lands and Forests in a newly opened forest insect laboratory. One of the men and one of the women indicated that they had been divorced. The remaining seven unmarried women taught continuously for an average of 40 years until they retired. One woman taught in the same elementary school in downtown Toronto in the same grades (kindergarten and grade one) for forty years. In terms of educational attainment, all of the men and three of the women had earned a university degree at some point during their career. One of the male teachers earned a Master of Arts degree from the University of Toronto. Two of the men became principals, one a public school inspector and the fourth had a graduate degree and left classroom teaching to take a position at Toronto Teachers' College in the 1960s. Two women became principals while another served as an acting principal in a small northern Ontario community but did not continue in that role when she moved to a larger urban centre.

The careers of the married women were interrupted for two reasons: the marriage bans for female teachers which were in effect until the early 1940s or childbearing after the bans were lifted. There was however one exception; a woman who taught in an isolated northern Ontario community near Sault Ste. Marie married in 1938 and retained her position. It was her understanding that she kept her job because no men were attracted to work in that isolated community. One of the women and one of the men left teaching to serve in the war in the 1940s and returned to their jobs after the war ended.

Two of the woman began their teaching careers in 1920 when teaching in a oneroom ungraded rural school could be considered the norm. ${ }^{23}$ Except for five teachers who began their careers very near or in Toronto, all had experienced teaching in a one-room country or rural school. Although there may have been characteristics in common, teaching in a one-room school proved not to be a homogenous experience. The composition of the community, place (geographic location, remoteness, etc.) and time were factors that determined what that experience might be.

The representation of the work experience of the interviewees was a mixture of independence, regulation and surveillance. The latter stemmed from the fact that the 
community and the expectations it had for the women and men who taught their children was ever-present and ever vigilant in one form or another. Then, there was always the possibility of an unexpected visit from the public school inspector. As recounted by most teachers, this proved to be a largely unpleasant experience. There was one exception. Victoria, whose father was a school principal during that time, remarked that she had no fear of inspectors because, "I was friendly with them on a social standing and when they came in I'd just treat them like friends. I had no fear of inspectors." 24 Sharon, on the other hand, explained that: "You had all the freedom that you wanted but you knew that the inspector was over you and if you didn't do what you were supposed to do, you got it. If it was bad enough he could make you leave. He could say you were gone." 25

\section{Narrative Disruption}

Gardner and Cunningham made extensive use of oral history as a basis for historical research into the teaching profession in Great Britain and explored the nature of oral history work and methodological challenges this posed for a discipline that relied so much on documentary methods. ${ }^{26}$ Oral history entailed shifting the emphasis of historical research away from institution and policy research towards exploring how teachers understood their professional lives. Their work in this field led to them to identify the deeper significance of the wartime evacuation of state school teachers and pupils. They wrote that the "process of evacuation during World War Two was one of the greatest collective experiences of social change seen in the course of the twentieth century." 27 The testimony of teachers revealed that the intimacy of this experience had the effect of leading teachers to different ways of perceiving children. ${ }^{28}$

In a later work, Philip Gardner noted that recognizing the importance of the self recounting and revealing its memories of lived experiences could be seen as "a departure from the narrow objectivist ambitions of traditional historical realism." ${ }^{29}$ Phillip Gardner identified one of the most important challenges posed by the use of oral history in education the "epistemological justification" for a method "which can confidently place a knowing foundational self at its heart." ${ }^{30}$ This statement is a powerful and pithy summation of some of the lingering problems posed by oral history and memory as historical method.

Gardner's analysis of the problematic of oral history identified the central role of narrative identity in the function of memory. ${ }^{31} \mathrm{He}$ is in agreement with Paul Ricoeur's assertion that narrative identity is generally engaged towards making coherence rather than truth (factual accuracy). ${ }^{32}$ In Gardner's view "this does not mean that its product should be seen as a distortion of the past. It is rather a mediation of it. Above all, neither does it mean that, despite its pre-eminent place, narrative identity in any way consumes the full potential of individual memory." ${ }^{33}$ In distinction to utilizing narrative identity in a hermeneutic approach, i.e., interpreting the meanings of narrative events, Gardner seeks to engage private memory in an historical approach that seeks to interrupt or disrupt narrative and redirect memory from a repetition of the familiar to a recollection of the forgotten or seldom considered. ${ }^{34}$ 
For Gardner the potential of narrative disruption exists in the possibility of moving away from the interpretation of speech acts to evaluating truth claims and "liberating memory" by enabling it to address evidence found in documentary sources. ${ }^{35}$ What Gardner hoped to achieve through narrative disruption is an oral narrative that identifies parallels between the spoken word and documentary sources. In Gardner's framework oral narrative has more in common with traditional historical narrative and is not to be confused with narrativity that orients itself around questions of meaning and identity. The concept of narrative disruption has a bearing on the distinction that Gardner made between the approach of life history and oral history. The former considers "narrative on its own terms as a constructed purposeful account" and leads to a hermeneutic emphasis while the latter takes narrative as the starting point to probe individual memory to for more, precise, detailed or verifiable information about the past to the recollection of the "seldom-related" or "almost-forgotten" occurrence rather than the event. ${ }^{36}$

One of the difficulties inherent in the method of narrative disruption centres on the difficulties it poses for interviewees. For the latter, it demands a move away from the patterns of repeating the familiar and rehearsed. As Gardner noted, the disruption of narrative asks that an interviewee makes "the laborious shift from the refiguration of present narratives to the configuration of past events." ${ }^{37}$ This often involves moving from the familiar, stable memory of the narrative of identity to the non-narrative fragment of events that perhaps are only vaguely remembered. This was precisely the intent of this project. This study utilized photocopies of two newspaper clippings from the 1930s as memory goads as a means of disrupting interviewee narratives away from patterns of repetition - what Gardner termed "the rehearsal of narrative identity" - towards the recollection of discrete memories.

The two newspaper clippings that were used referred to events directly related to the introduction of the new course of studies in 1937. The first reported on the annual convention of the Ontario Education Association (OEA) in April 1937 where the reportage of the entire page focused on the new curriculum about to be introduced in September of that year. ${ }^{38}$ The other related to the appointment of Thornton J. Mustard to the position of principal of Toronto Normal School in September of 1938. Mustard had been on the staff of Toronto Normal School for many years prior to his appointment as its principal and would have been a familiar figure to the eleven teachers who acquired their teacher training there. Mustard was also a central figure in the creation and promotion of the new curriculum. The newspaper clippings were introduced after the interviewees had responded to a series of questions about their experiences in general and after a series of specific questions about their experiences teaching during the Depression. Both series included questions that were sufficiently open-ended to create opportunities for interviewees to make general observations about curriculum and pedagogy.

The Programme of Studies for Grades 1 to VI of the Public and Separate Schools was introduced in 1937 by the Liberal government of Mitchell Hepburn a few years after defeating the Conservatives in the 1934 election. In an unprecedented move, Premier Mitchell Hepburn purged the civil service and Department of Education 
of the Conservative stalwarts who had controlled the Department of Education for 30 years. ${ }^{39}$ In 1938, a year after the new course of studies had been introduced, Thornton Mustard a "progressive" was appointed principal of Toronto Normal School. ${ }^{40}$ Mustard's appointment was crucial because he and Stanley Watson, principal of Keele Street Public School in Toronto, had been responsible for creating the new curriculum. Mustard's appointment as principal positioned him to play an important role in promoting the new vision of the child, pedagogy and the curriculum. Toronto Normal School was arguably one of most influential normal schools in the province; its founding in 1847 was linked to Egerton Ryerson's earliest attempts to regulate and normalize teacher training in the province.

The new course of studies had been two years in preparation and both Mustard and Watson traveled to various parts of the province during the months of April, May and June of 1937 to meet with normal school staffs, inspectors, principals and teachers in order to discuss and receive criticisms and suggestions regarding the proposed revisions of curriculum and pedagogy. ${ }^{41}$ The new curriculum was launched amid high hopes and expectations. In a newspaper report on his appointment - a year after the launch of the new curriculum - Mustard stated that the changes introduced in 1937 meant that "the role of the teacher had changed; he [sic] has become a guide and helper rather than a driver and taskmaster." 42 The impression here is that the changes introduced a year earlier had already had an impact.

The new curriculum document was distributed to all elementary school teachers in the province in August of 1937. Known as the "little grey book" because of its distinctive grey cover, the Programme, 1937 differed markedly from its predecessor document Courses of Study for Public and Separate Schools. The latter, which outlined curriculum for all the forms of the public school, comprised a mere thirty-six pages, while the Programme, 1937 which dealt with curriculum and pedagogy for pupils in grades I to VI was much more substantial numbering one hundred thirty pages. Since its introduction in 1937, various iterations of the "little grey book" served as the official curriculum and pedagogy in Ontario until the revisions of 1968.

News of the introduction of the new course of studies in the fall of 1937 was preempted by reports of the outbreak of polio. ${ }^{43}$ The severity of the outbreak resulted in serial delays in the opening of elementary, secondary and normal schools in Ontario and other parts of Canada. Schools in Toronto finally opened on October 12 - a full month after school was initially scheduled to start. ${ }^{44}$

\section{Teacher Narratives}

The interviewees had a number of opportunities to recall memorable events and/or significant changes that they may have experienced throughout their career before the introduction of any of the memory goads. The questions were posed in a general way and again when the interview shifted to focus on their experiences teaching during the 1930s. These open-ended questions elicited two responses that related to 1937. When asked to identify any significant changes that he experienced during his career, William, who became a public school inspector in 1947, responded with the view that: 
One of the greatest changes was the introduction of the new curriculum about... that would be about 1938...I think. The curriculum was changed to present a more flexible program and...new textbooks were brought in... and choice of textbooks. Prior to that there was one book for each grade. You had one a year... a brown reader. Everybody had to use it...the brown reader. ${ }^{45}$

In response to the same question, Helen referred to the polio outbreak that delayed the opening of schools in 1937 and the difficulties that ensued when her future brother in law became afflicted. ${ }^{46}$ No other teacher referred to either of these two events without being prompted by the memory goads. Instead they recalled events such as the introduction of special education classes; two mentioned becoming a principal; a few mentioned their first school and two women recalled being dismissed from their teaching positions because they had married in 1939.

Questions about their teacher training experiences in normal school, on the other hand, prompted three teachers who attended Toronto Normal School to include Thornton Mustard in their recollections. Helen recalled that, "some of the masters I had at normal school [laughter]...I always felt that they got there because the Department [of Education] didn't know where else to put them. But Dr. [sic] Mustard was a leader and his lectures were delightful." ${ }^{47}$ Helen's understanding how appointments to normal schools were made had the ring of truth; because they were under the political control of the Department of Education, appointments to normal schools were made by an order-in-council.

David attended Toronto Normal School in 1931 and questions about what the focus of his teacher training had been prompted him to recall that "It was motivation of the class and then it was the presentation and then there was eventually testing. There was...I think he was the vice principal Mr. Thornton Mustard, the most wonderful man I've ever met. He was just excellent. He was a little fellow but Thornton Mustard was just a wonderful example." 48 When Hanna was asked about where she received her teacher training she replied by simply stating "in Toronto with Mr. Mustard." 49

The newspaper clippings focused the attention of the interviewees on the changes made in 1937 and elicited responses where none had been previously given. The responses to the newspaper clipping about Thornton Mustard's appointment as principal of Toronto Normal School were more fulsome than those about the new curriculum. Victoria attended Hamilton Normal School in 1932 and stated that she was familiar with Mustard and added that her father, a school principal at the time, knew the former. Her association with Mustard was that "he was bringing new ideas in education." ${ }^{50}$ Robert who began teaching in Lambton County in southwestern Ontario before moving to Toronto 1933 recalled Thornton Mustard and remembered "there was a little grey curriculum book and, and I think likely he was an author of that." 51 However, Robert was unable to describe or provide any details about the curriculum or its intent.

James, who attended Toronto Normal School and taught in Toronto during the 1930s and later joined the faculty at Toronto Teacher's College, recalled Mustard quite vividly; he recalled both Mustard and the new curriculum. His recollection 
about Mustard was that "he was a long way ahead of his time in education. And I remember when he lost his life on the Athenia. He was a way ahead of his time. He was more of Hall-Dennis approach to education." ${ }^{52}$ About the new course of studies James stated the following: "I recall that it was more flexible. There was more choice on the part of teachers as to what and how most of the time. There was a certain amount of guidance as to the contents. It was much more flexible." ${ }^{53}$

Thornton Mustard perished in the sinking of SS Athenia on 3 September 1939 and it is this event that a number of teachers readily recalled and associated with the former. ${ }^{54}$ Even though her recollections of the dates weren't quite accurate, Jennifer went so far as to suggest that Mustard's untimely death was significant for the success of the new curriculum:

Oh yeah the man who, that went down in the ocean. Yes, I remember, that was just about the time of 1936 or 1937 I think isn't it? When the new course of studies came out in 1937 we all said that if Mr. Mustard hadn't been drowned in the ocean everything would have been different. ${ }^{55}$

"You know he was marvelous" was Margaret's response to the newspaper clipping announcing Mustard's appointment as principal of Toronto Normal School. When queried about the new course of studies Margaret recalled vividly that:

It nearly drove our principal crazy. He thought he couldn't get it through his head just. I paid no attention to it 'cause I had my own way of teaching and paid no attention to any of it. They left me alone and I taught successfully. ${ }^{56}$

The fact that Margaret "paid no attention to it" provides an explanation for why she couldn't offer any insights about what she thought the intent was of the new course of studies. Probed about whether teachers were offered assistance with the new course of studies Margaret said,

We were invited to go you'd be asked to go after school listen to something or other and then you'd go you'd nearly be sick listening to how they wanted you to teach. And I thought to myself "I could never teach that way." It would nearly make me sick and I'd come home and forget all about it. ${ }^{57}$

The new curriculum was clearly a challenge for Margaret. She summarized the method of teaching that it advocated as being "too much incidental. They didn't get to the nitty gritty." Asked to describe her method of teaching Margaret responded by saying:

Well we were taught how to do it at school and you twisted it around to suit your own style of teaching the children. And the way I would always teach them I converted everything I learned at normal school to my way of teaching. I used the basics but I developed my style. ${ }^{58}$ 
Asked to elaborate what her style was she replied "Story telling, story way. When they had memory work to do, that was fine but I'd rather that they would tell me anything that they wanted to tell you in their own words." ${ }^{59}$ Margaret taught continuously in various grades of the same elementary school in mid-town Toronto for thirty-eight years and claimed to have taught the same way throughout her entire career explaining that "I never had anybody complain and I didn't teach any differently than I had ever taught before." ${ }^{00}$

Continuity was a significant aspect of Margaret's recollection of her career, children and teaching in general and her representation of the latter was stated without any hint of irony. In her view "as long as you kept to your course of study and you covered it and the children were successful they left you alone." ${ }^{61}$ For Margaret, following the new course of studies introduced in 1937 and the epistemological shift in the concept of learning that it advocated engendered no contradictions - she simply ignored what it asked teachers to think about or consider in their practice.

Alice replied to the newspaper clipping about Thornton Mustard by saying "Oh, Thornton Mustard. I can't just recall. He wrote the teacher's manual, didn't he?" ${ }_{2}$ The memory prompted Alice to recall that the new course of studies formed the basis of her teacher training at Stratford Normal School in 1937; she stated that "I wasn't familiar with the one before but I was with the new one. It's the new one I was familiar with because that's the one we studied at teachers college." ${ }^{63}$ Alice could not provide any details about either the intent of the new curriculum or how it was different from the previous version. Helen, on the hand, offered the following assessment of teaching, schooling and the curriculum before the new course of studies was introduced in 1937:

Well, the daily routine didn't have much to inspire either a teacher or a child. We were in a pattern that didn't give you any chance to explore anywhere. This was your course of study, this you better follow and if you had something new that you wanted to try out you were loathe to try for fear of the criticism you were going to get from your inspector particularly. I don't think inspectors were much more inspiring than some of the Department people maybe. ${ }^{64}$

Helen mentioned that the new curriculum sought to place an emphasis on the child but added that "when we had forty children in the classroom you couldn't have emphasis too much on an individual child. When you got fewer children then naturally your interest in the individual became greater." ${ }^{\prime 5}$

A scarcity of teaching positions in southern Ontario prompted Mary to respond to an advertisement in The Globe and Mail newspaper for a teaching position in a remote, isolated and sparsely populated community near Sault Ste. Marie in northern Ontario. She moved to different schools closer to an urban area but remained in the north for her entire thirty-nine year career. Mary also recalled Thornton Mustard through the sinking of SS Athenia ${ }^{66}$ She summarized her understanding of the intent and changes intended by the new curriculum by stating, "Well I think for one thing the idea was to get children to hunt up material for themselves. It wasn't just handed 
out to them you know this type of thing." ${ }^{67}$ This was her version of a more childcentred curriculum. Mary didn't mention the reforms of 1937 when asked to identify a memorable or significant event in her career. Instead, she replied, "I think when the Hall-Dennis Report came out. Well, to my way, it wasn't exactly an improvement." ${ }^{68}$ Was her recollection of the Hall-Dennis Report made memorable due to the fact that it appeared so near to the end of her career and caused her to overlook the arguably more significant reforms that occurred at the beginning of her career in 1937? Or, was the gap in memory due to the fact that Mary taught alone in the periphery - in a region of Ontario far removed from the centre of change and innovation - that made this event less significant?

Continuity and perhaps a lack of a deeper understanding of the new curriculum was evident in Molly's recollection in response to the newspaper clipping about the new course of studies. She recalled that her teaching was based on a syllabus noting, "I remember now the grey book...the syllabus...the curriculum was there and the province laid it down." Asked whether the grey book suggested ways of teaching Molly responded by saying, "No we were supposed to learn how to teach at normal school." ${ }^{69}$ No doubt there is some truth in this statement. Molly attended Toronto Normal School in 1928 where Thornton Mustard was the English Master and yet she could not recall any details about Mustard or the salient aspects of the new course of studies and its attempt to encourage new methods of teaching. As noted above, Hanna recalled her teacher training with Thornton Mustard, but her recollections of pedagogy and the new course of studies were vague; she remembered that "the emphasis was on...we had that little grey book a new curriculum book that had come out and participation in the community." 70

Anne also attended Toronto Normal School in 1928 and recalled Mustard fondly: "We all liked him so well. He was very enthusiastic about us teaching good English to the children and we just took it all in and thought he was wonderful."71 She recalled that Mustard stressed a particular method of teaching but could not provide any details about what that entailed. Anne remembered that Mustard "seemed to be so interested in us that he wanted us to teach children all the basics of English and he would just give us a wonderful thing to go away with. I don't know how you would explain it but he was just great." ${ }^{72}$ Anne's recollection of any particulars of the new course of studies or methods of teaching was somewhat murky; however, she suggested that she and her classmates at normal school did try the new ideas "in our teaching as we went out."73

After graduating from Toronto Normal School, Anne returned to teach in oneroom country schools in Grey County. Anne reported that she enjoyed doing things differently but encountered obstacles in the form of an inspector. At one school, Anne said that "we had an old iffy inspector. I didn't like him and he didn't like me. I had a time there." Her recollection was that:

I liked doing other things and one day he came into my classroom unexpectedly and I wasn't teaching exactly what I was supposed to on that day and that didn't work out very well. He told me, this was at noontime, and he said "When I come back I want you to be teaching what's on your daybook."74 
Sharon taught in Hastings County east of Toronto and had a similar recollection about the new course of studies and her school inspector. Her remembrances had little to do with experimenting or trying to teach differently and more to do with following the curriculum organized in the document: "that grey book - it just laid down everything in every subject and the inspector would look at your grey book if you didn't have them ticked off you were in trouble." 75

Two teachers who taught in remote regions of northern Ontario had no recollection of either Thornton Mustard or the new course of studies introduced in 1937. Florence and Josephine were both born and raised in northern Ontario and attended North Bay Normal School. Florence's response to the introduction of the memory goad about Thornton Mustard was simply "Mustard? I know what mustard is [laughter]." She was unable to recall anything about the introduction of the new course of studies in 1937. Instead, Florence referred to the changes that occurred after the publication of the Hall-Dennis report in 1968 as being a significant event. She explained: "I remember when they changed the program at the public school here. They took the seats away and put tables and junk...that would be in the late sixties I guess." ${ }^{.6}$

Josephine on the other hand attended North Bay Normal School in the fall of 1937 when the new curriculum went into effect and presumably would have been a significant part of her teacher training. When probed, she explained: "I can't remember that [the new course of studies] excepting that I know we had a curriculum... we knew what we were supposed to be teaching and I don't...I can't just remember whether we got that through the principal or..." ${ }^{77}$ Josephine left the profession after eight years and took a position with the newly opened forest insect laboratory in Sault St. Marie. She offered the candid assessment of her own teaching abilities by explaining: "I don't particularly think I was inspired enough to realize that these kids were getting an education towards a goal and that I should encourage them or that sort of thing you know." " 8 She added that, "I had a lot more things on my mind than just making kids very educated children... you know because when you're young you do have other things on your mind." 79 Josephine did not specify what those other things might have been and the interviewer chose not to pursue this line of questioning.

Somewhat unexpectedly, six teachers referred to the Hall-Dennis Report as the harbinger of significant change in the elementary schools of Ontario. The HallDennis report was the common term used for the 1968 landmark document prepared by The Provincial Committee on Aims and Objectives of Education in the Schools of Ontario that heralded a "progressive" pedagogical tradition in Ontario educational policy. ${ }^{80}$ This policy dominated elementary schooling until 1995 when the Common Curriculum was introduced. ${ }^{81}$

The recollections about the importance of the Hall-Dennis report are particularly interesting because the Programme of Studies for Grades 1 to VI of the Public and Separate Schools 1937 was of great interest to the committee which published its report in 1968. The Hall-Dennis committee explained the significance of the 1937 programme by stating that, "The simple but startling truth is that virtually every idea in it, with only one immediately noticeable exception, might have been expressed by educationally enlightened and advanced authors today." ${ }^{82}$ The viewpoint of the 
Provincial Committee in 1968 invites the question: if The Programme represented "enlightened" educational ideas in 1937, why was it so little remembered by the teachers who taught when it was introduced during the 1930s? I would suggest that there is an aspect of forgetting that is of a piece of Hacking's memoro-politics and the politicization of memory. ${ }^{83}$ Culturally and politically, the Hall-Dennis report of 1968 has been defined as heralding the most significant changes ever introduced to the elementary schools of Ontario. This cultural remembrance however is at the expense of forgetting the equally significant changes that were attempted in 1937.

\section{Conclusions}

Uneven educational development was one aspect of the ongoing "rural school problem" that made reform difficult to implement in Ontario. ${ }^{84}$ This pattern of uneven educational development can be viewed in terms that are analogous to Wallerstein's concept of a core-periphery model of capitalist development. ${ }^{85}$ Educational discourse, practices and resources circulated outward from the centre toward peripheral or rural areas. Teachers who taught in rural and remote areas at some distance from the centre had limited or no access or exposure to teacher-in-service training in the new methods and practices such as was the case in Toronto and other larger urban centres. ${ }^{86}$ This helps explain why teachers who taught in rural or peripheral areas seemed to have only vague recollections — if any at all — of the new course of studies introduced in 1937.

The difficulties and the differences between rural and urban areas were reflected in the oral testimony of teachers. Attracted by the larger salaries and increased opportunities, Robert moved to Toronto in 1934 after having taught for four years in a oneroom country school in Lambton County near his birthplace in southeastern Ontario. His recollection was that "in those days the people in the rural areas didn't get a fair shake. On the whole, they had poor buildings, they had poor equipment, they had the poorest qualified teachers." ${ }^{87}$ It is not clear what criteria Robert used to make his judgments about teachers; however, he did become a principal later in his career and perhaps drew on that experience. Florence didn't draw any comparisons yet matter-offactly described how she partitioned her one-room school in a remote area of northern Ontario with a curtain and lived there from early November until the spring because heavy winter snows impeded daily travel to and from school. The situation Florence described typified the conditions endured by many isolated, relatively inexperienced young woman working in outlying and rural areas of Ontario are comparable those faced by beginning teachers in pre-World War Two Alberta. ${ }^{88}$ While it may be true, as Patterson argued, that the willingness of these women to endure in order to provide a modicum of educational service formed the basis of "a professional support system" that paved the way for subsequent generations of teachers, it is equally true that these conditions were not congenial for making educational change. ${ }^{89}$

There was precious little in the recollections of teachers to suggest that they understood or were aware of the deeper significance of the changes attempted in 1937. Teachers who studied at Toronto Normal School were certainly influenced by the 
beliefs, principles and methods espoused by Thornton Mustard; however, what is less certain is the extent to which those teachers had more than superficial understanding of the deeper significance of the new curriculum. A reading of the document Programme of Studies for Grades 1 to VI of the Public and Separate Schools reveals its intent was nothing short of an epistemological shift that positioned the child as the initiator and source of learning. At best, teachers described and understood this new course of studies introduced in 1937 as providing a measure of flexibility and perhaps an opportunity for children to do things for themselves.

It is almost certain that the untimely death of Thornton Mustard in 1939 had a negative effect on the promotion of the new course of studies and the training of teachers at Toronto Normal School and throughout the province. Was Mustard ahead of his time? I don't believe so. Rather, he was very much of his time. The reforms he co-authored with Stanley Watson were very much a piece of the various strands of what can be loosely referred to as progressivism that had been circulating globally for years. There is little evidence to suggest that Thornton Mustard was a social reformer or that the changes to education in 1937 had social reform as their objective. Mustard could be described as a pedagogical reformer and the education reforms in Ontario were consistent with that concept: a better understanding of children would lead to school reform. This was different from the social reconstructionist intent of Alberta school reforms led by individuals such as H.C. Newland who were convinced, as von Heyking points out, that schools were the means of reconstructing society on a progressive basis. ${ }^{90}$ This contrast between the various concepts referred to as "progressive education" gives credence to Brehony's argument that the term needs to be considered in greater specificity. ${ }^{11}$

The oral testimony of teachers provides some evidence to support the assessment of historians such as Robert Patterson who suggested that the extent of change that resulted from Canadian experimentation with "progressive education" was superficial. ${ }^{92}$ However, it is not altogether clear that the legacy of this experimentation was as short-lived as Patterson has suggested. Present circumstances offer little evidence to counter Amy von Heyking's finding that one of the lasting outcomes of progressivism in Alberta was the establishment and legitimization of the putative expertise of the educational bureaucrat. The findings of the present study are in accord with those of Lemisko and Clausen who argued that due to a lack of a coherent epistemology and pedagogy efforts to reform elementary schooling in Alberta and Ontario resulted in combination of the traditional and the progressive. ${ }^{93}$

The method of narrative disruption proved fruitful in prompting historical narratives that might otherwise have been lost. The oral history accounts of the reception of the new course of studies introduced in Ontario schools in 1937 suggest that this curriculum was neither a great success nor a complete failure. There were teachers who were grateful for its implementation just as there were teachers who "paid no attention" to the attempts at "liberalizing" a curriculum and pedagogy that was moribund and gave no leeway for teachers to experiment. It is highly unsatisfying to conclude that some teachers, even a majority, were quite satisfied with the status quo while others were not, and yet this might indeed be the case. It is also suggestive of a 
more profound question that relates to the notion of continuity itself and the difficulties encountered by the subject contemplating or encountering a disruption of the patterns of a life that seeks meaning in repetition of the familiar and known. The new course of studies introduced in 1937, however, was precisely that; it asked teachers to think and teach differently. The simple truth is that some teachers took up this challenge while the majority was unwilling or unable to do so. The experiments of 1937 were not an abject failure nor were they a resounding success. However, schooling in Ontario had to wait another thirty years before the basic concepts of the 1937 curriculum were restated and taken up with a renewed interest that resulted in broader implementation and greater success.

\section{Notes}

1 Department of Education, Programme of Studies for Grades I and VI of the Public and Separate Schools, 1937, (hereafter Programme).

2 W.G. Fleming, Ontario's Educative Society / III: Schools, Pupils and Teachers (Toronto: University of Toronto Press, 1971), 9.

3 Robert Stamp, The Schools of Ontario, 1876-1976 (Toronto: University of Toronto Press, 1982), 182. Milewski suggests that the significance and lasting impact of the 1937 curriculum lay in the rupture in pedagogical discourse that resulted in a broad range of normalizations related to the concept of the child and learning being inscribed in the pedagogic archive. Patrice Milewski, "'The Little Grey Book': Pedagogy, Discourse and Rupture in Ontario in 1937," History of Education 37 (2008): 91-111.

4 Robert S. Patterson, "The Implementation of Progressive Education in Canada," in Essays on Canadian Education, ed. Nick Kach, Kas Mazurek, Robert S. Patterson, Ivan DeFaveri (Calgary: Detselig Enterprises Ltd., 1986), 79-93.

5 Amy von Heyking, "Selling Progressive Education to Albertans, 1935-1953," Historical Studies in Education/Revue d'histoire de l'éducation 10 (1998): 67-84.

6 Lynn Speer Lemisko and Kurt W. Clausen, "Connections, Contrarities, and Convolutions: Curriculum and Pedagogic Reform in Alberta and Ontario, 1930 1955," Canadian Journal of Education 29 (2006): 1118.

7 Cecilia Reynolds and Harry Smaller, "Ontario School Teachers: A Gendered View of the 1930s," Historical Studies in Education/Revue d'histoire de l'éducation, 6, 3 (1994), 151.

$8 \quad$ Ibid., 151.

9 Ibid., 153.

10 Ibid.

11 School inspection was an exclusively male domain until 1919 when Dr. Aletta Marty (1865-1929) was appointed as a school inspector in Toronto and became the first woman to hold such a position in Canada. A search through the reports of the Chief Inspector of Public School and Separate Schools does not indicate that any women were appointed to this position during the 1930s.

12 The interviews were conducted, tape-recorded and transcribed by the researcher. Each participant signed a consent form assuring anonymity and consequently pseudonyms have been used in this article. They were also informed that only selections from the transcripts would be used for research purposes and the writing of articles. Each of the participants was made aware that the interviews would focus on their teaching experiences during the 1930s. This gave each interviewee an opportunity to reflect on what they might choose to divulge or withhold. The in-depth interviews were 
semi-structured and between one and two hours in duration. The interviews began with general questions about each subject's identity and overview of experiences in teaching before focusing on their teaching experiences during the 1930s. Pauses, both short and long, and shifts where one uncompleted thought or sentence ran into another are indicated by three dots (...), otherwise, the quotations used in this article appear as they were recorded and transcribed.

13 Portelli asserts that "oral sources tell us not just what people did, but what they wanted to do, what they believed they were doing, and what they now think they did." Alessandro Portelli, The Death of Luigi Trastulli and Other Stories: Form and Meaning in Oral History (Albany: State University of New York Press, 1991), 50.

14 Luisa Passerini, "Women's Personal Narratives: Myths, Experiences, and Emotions," in Interpreting Women's Lives: Feminist Theory and Personal Narratives, ed. Personal Narrative Group (Bloomington and Indianapolis: Indiana University Press, 1989), 197.

15 Angela Davis, “'Oh no, nothing, we didn't learn anything': Sex Education and the Preparation of Girls for Motherhood, c.1930-1970," History of Education 37, (2008): 662-663.

16 Ian Hacking, Rewriting the Soul: Multiple Personality and the Sciences of Memory (Princeton: Princeton University Press, 1995).

17 Ibid., 210-220.

18 Ibid., 209.

19 Ibid. The politicization of memory is an important component of Hacking's inquiry.

20 Rebecca Priegert Coulter and Helen Coulter eds., History is Hers: Women Educators in Twentieth Century Ontario (Calgary: Detselig Enterprises Ltd., 2005).

21 Ibid., 23.

22 Louise, interviewed by the author, 22 March 1999.

23 Department of Education, Household Science in Rural Schools (Toronto: William Briggs, 1918), vii. This pedagogic manual noted that there were 5,697 rural schools compared to 903 urban schools in the province in 1918.

24 Victoria, interviewed by the author 17 March 1999.

25 Sharon, interviewed 23 March 1998.

26 Philip Gardner and Peter Cunningham, "Oral History and Teachers' Professional Practice: a Wartime Turning Point?” Cambridge Journal of Education 27 (1997): 331-342.

27 Ibid., 334.

28 Ibid., 335.

29 Philip Gardner, "Oral History in Education: Teacher's Memory and Teachers' History," History of Education 32 (2003): 175.

30 Ibid., 176.

31 Ibid., 180.

32 Paul Ricoeur, Time and Narrative, Vol 3 (Chicago University Press, 1988), 246 as cited in Gardner, "Oral History," 180.

33 Ibid.

34 Ibid., 181.

35 Ibid., 183.

36 Gardner, "Oral History," 181. Gardner notes that distinction between event and the occurrence is borrowed from Paul Ricoeur, Oneself as Another (Chicago: University of Chicago Press, 1992), 142.

37 Gardner, "Oral History," 185.

38 "New Era in Education Advances." The Globe and Mail, 6 April 1937, 9. A full page was dedicated to reporting on the new curriculum.

39 This is documented in greater detail by Robert Stamp in Schools of Ontario, 155. 
40 J.G. Althouse, Chief Director of Education for the Province of Ontario, described Mustard as "an outstanding apostle of freedom amongst us." Toronto Normal School, 1847-1947 (Toronto: School of Graphic Arts, 1947).

41 Annual Report of the Minister of Education for the Year 1937, (hereafter, Annual Report), 9.

42 "Thornton J. Mustard Appointed new Principal of Normal School," The Globe and Mail, 13 September 1938, 4.

43 Rutty pointed out that management of the epidemic in Toronto was the focus of numerous controversies especially as it pertained to school openings and the closing of parks, churches, and public pools. Christopher J. Rutty, "The Middle Class Plague: Epidemic Polio and the Canadian State," Canadian Bulletin of Medical History, 13 (1996): 277-314.

44 “Doctors to Guard Against 'Polio' in Schools." The Globe and Mail, 6 October 1937. 4. The article reported that a decision had been made to opens schools in Toronto the following Tuesday (October, 12).

45 William, interviewed by the author, 29 August 1998.

46 Helen, interviewed by the author, 22 June 1998.

47 Helen. Thornton Mustard did not have a doctoral degree.

48 David, interviewed by the author, 21 March 1999.

49 Hanna, interviewed by the author, 15 August 1998.

50 Victoria, interviewed by the author, 17 March 1999.

51 Robert, interviewed by the author, 11 April 1999.

52 James, interviewed by author, 25 October 1998. The reference is to the 1968 document Living and Learning produced by The Provincial Committee on Aims and Objectives of Education in the Schools of Ontario commonly known as the Hall-Dennis Report. It was named after the two co-chairs of the committee: Justice M. Hall and Mr. Lloyd Dennis.

53 James, interviewed by author, 25 October 1998.

54 "Normal School Head is Feared Victim of Sub." The Globe and Mail, 14 September $1939,5$.

55 Jennifer, interviewed by the author, 20 August 1998.

56 Margaret, interviewed by the author, 29 June 1998.

57 Margaret.

58 Margaret.

59 Margaret.

60 Margaret.

61 Margaret.

62 Alice, interviewed by the author, 15 July 1998.

63 Alice.

64 Helen, interviewed by the author, 22 June 1998.

65 Helen.

66 Mary, interviewed by the author, 10 July 1998.

67 Mary.

68 Mary.

69 Molly, interviewed by the author, 20 July 1998.

70 Hanna, interviewed by the author, 15 August 1998.

71 Anne, interviewed by the author, 29 April 1999.

72 Anne.

73 Anne.

74 Anne.

75 Sharon, interviewed by author, 23 March 1998.

76 Florence, interviewed by the author, 15 March 1999. 
77 Josephine, interviewed by the author, 4 March 1999.

78 Josephine.

79 Josephine.

80 The Provincial Committee on Aims and Objectives of Education in the Schools of Ontario. Living and Learning (Toronto: Ontario Department of Education, 1968).

81 Carol A. Wien and Curt Dudley-Marling, "Limited Vision: the Ontario Curriculum and Outcomes-based Learning," Canadian Journal of Education 23 (1998): 405-420. Examines the outcomes-based learning that ushered a break in the child-centred pedagogy that dominated Ontario elementary schools since the publication of the HallDennis report in 1968.

82 Ibid., 70. The notable exception referred to by the committee was the emphasis placed on religion in 1937.

83 Hacking, Rewriting, 214. Hacking wrote that the erosion of memory is not a topic for memoro-politics; rather, the latter concerns the politics of a forgotten event.

84 Stamp provides an ongoing synopsis of the rural schools beginning in the nineteenth century, 1920s and 1930s respectively. Stamp, Schools of Ontario, 59, 61-64; 122-131; 144, 146, 156.

85 Immanuel Wallerstein, The Modern World-System (New York, London: Academic Press, 1974), 223-297.

86 Wilson examined the difficulties faced by rural women teachers in British Columbia during the 1930s. J. Donald Wilson, "I am ready to be of assistance when I can": Lottie Bowron and Rural Women Teachers in British Columbia," in Women Who Taught: Perspectives on the History of Women and Teaching ed. Alison Prentice and Marjorie R. Theobald, (Toronto: University of Toronto Press, 1991), 202-229.

87 Robert, interviewed by the author, 11 April 1999.

88 Robert S. Patterson, "Voices form the Past: The Personal and Professional Struggle of Rural School Teachers," in Schools in the West: Essays in Canadian Educational History ed. Nancy M Sheehan, J. Donald Wilson, David C. Jones (Calgary: Detselig Enterprises Limited, 1986), 99-111.

89 Ibid., 110.

90 Amy von Heyking, "Selling Progressive Education," 70.

91 Brehony reviewed both writing as well as the various meanings that have been appended to the term progressive education. Kevin J. Brehony, "From the Particular to the General: The Continuous to the Discontinuous: Progressive Education Revisited," History of Education 30 (2001): 413-432.

92 Patterson, "Implementation of Progressive Education," 110.

93 Lemisko and Clausen, "Connections, Contrarities, and Convolutions," 1119. 